\title{
Hubungan Kemampuan Pemecahan Masalah dengan Efikasi Diri Siswa SMAN 1 Banuhampu
}

\author{
Pipit Firmanti ${ }^{1}$, Doni Ardia Putra ${ }^{2}$, Sri Cantika Padang ${ }^{3}$ \\ 1,2,3 Institut Agama Islam Negeri (IAIN) Bukittinggi, Bukittinggi, Indonesia \\ *Corresponding Author
}

\begin{tabular}{l} 
Informasi Artikel \\
\hline Diterima Redaksi: 10 Juni 2021 \\
Revisi Akhir: 20 November 2021 \\
Diterbitkan Online: 31 Desember 2021 \\
Kata Kunci \\
\hline Kemampuan Pemecahan Masalah, \\
Efikasi diri \\
Korespondensi \\
\hline E-mail: firmantiyuberta@gmail.com
\end{tabular}

\begin{abstract}
A B S T R A C T
Problem solving which is an important component in mathematics contributes to the development of the times. However, this ability is still not fully mastered by students. Therefore, there needs to be further research related to the causes of the low problem solving ability of students. One of them is self-confidence (self-efficacy). The purpose of this study was to describe the problem solving ability and self-efficacy of students and to see the relationship between the two. The method used is descriptive qualitative. The research subjects taken were 34 students of class XI MIPA 1 at SMAN 1 Banuhampu. In this study, there were two instruments used were self-efficacy questionnaires with problem-solving ability tests. The analysis shows that (l) there are still students who cannot work on the questions given by leaving the answers blank (2) Between problem solving and self-efficacy has a very weak or very low correlation where $r=0.0094$. (3) Almost all students have good self-efficacy which is at a fairly low to high level.
\end{abstract}

Pemecahan masalah yang merupakan komponen penting dalam matematika turut andil dalam perkembangan zaman. Namun, kemampuan ini masih belum sepenuhnya dikuasai oleh siswa. Oleh karena itu, perlu ada penelitian lanjutan terkait penyebab rendahnya kemampuan pemecahan masalah siswa. Salah satunya adalah kepercayaan diri (efikasi diri). Tujuan dari penelitian ini adalah untuk mendeskripsikan kemampuan pemecahan masalah dan self efikasi siswa serta melihat hubungan di antara keduanya. Metode yang digunakan adalah deskriptif kualitatif. Subjek penelitian yang diambil adalah 34 siswa kelas XI MIPA 1 di SMAN 1 Banuhampu. Dalam penelitian ini terdapat dua instrumen yang digunakan yaitu angket efikasi diri dan tes kemampuan pemecahan masalah. Analisis menunjukkan bahwa (1) masih ada siswa yang tidak dapat mengerjakan soal yang diberikan dengan mengosongkan jawaban, (2) antara pemecahan masalah dengan selfefficacy memiliki korelasi yang sangat lemah atau sangat rendah dimana $r=0,0094$. (3) Hampir semua siswa memiliki efikasi diri yang bagus dimana berada pada level cukup rendah hingga tinggi.

O2021 by the authors. Submitted for possible open access publication under the terms and conditions of the Creative Commons Attribution-ShareAlike 4.0 International License-(CC-BY-SA) (https://creativecommons.org/licenses/by-sa/4.0/)

\section{Pendahuluan}

Kemampuan pemecahan masalah adalah kemampuan untuk menerapkan pengetahuan yang telah dimiliki sebelumnya ke dalam situasi baru yang melibatkan proses berpikir tingkat tinggi.[1] Dilihat dari aspek psikologis, kemampuan ini merupakan proses yang melibatkan aplikasi dalil-dalil atau teorema yang dipelajari tapi melibatkan aktivitas berpikir yang cukup kompleks.[2]Dengan kata lain, pengetahuan yang telah diperoleh di kelas tidak semata-mata bersifat teoritis saja namun dapat diaplikasikan ke dalam dunia nyata atau di lapangan. Aktivitas dalam kemampuan ini dapat membentuk banyak karakter positif dalam diri siswa. Salah satunya karakter kerja keras.[3] Karakter seperti ini sangat diperlukan dalam menghadapi perkembangan zaman seperti saat sekarang ini. Sebaliknya, Ketidakmampuan individu dalam proses pemecahan masalah matematika akan berdampak pada tidak berkembangnya kemampuan fundamental matematis yang harus dimiliki individu.[4]Oleh karena itu, kemampuan ini harus dikembangkan.[5]

Kemampuan pemecahan masalah menjadi komponen penting dalam matematika. Kemampuan ini merupakan bagian utama dari tujuan pembelajaran yang ingin dicapai dalam pembelajaran matematika.[6] Namun, masih terdapat penelitian yang menunjukkan bahwa 
kemampuan pemecahan masalah siswa SMA masih rendah.[7] Oleh karena itu, perlu diteliti tentang faktor-faktor yang mempengaruhi hal ini salah satunya kepercayaan diri (efikasi diri).

Albert Bandura pertama kali mengenalkan istilah self-efficacy pada tahun 1997 sebagai hasil dari proses kognitif berupa keputusan, keyakinan atau penghargaan tentang seberapa siap individu memperkirakan kemampuan dirinya dalam pelaksanaan tugas atau tindakan tertentu yang diperlukan untuk mencapai hasil yang diinginkan. Hal ini tidak berkaitan dengan kemampuan yang dimiliki, tapi berkaitan dengan keyakinan individu mengenai hal apa yang dapat dilakukan dengan kemampuan yang ia miliki seberapa pun besarnya.[8] Efikasi diri dapat berupa kemampuan yang dirasakan seseorang untuk mengatasi situasi khusus misalnya situasi belajar untuk memperoleh prestasi yang tinggi.[9] Efikasi diri memiliki efek langsung yang kuat pada kecemasan, tetapi memiliki efek langsung yang lemah pada kinerja.[10]Penelitian terdahulu menunjukkan adanya pengaruh efikasi diri terhadap kemampuan berpikir kritis yang juga merupakan berpikir tingkat tinggi dalam matematika [11]. Sebaliknya, hubungan kemampuan pemecahan masalah matematika dan self-efficacy siswa termasuk kategori sangat rendah karena nilai $\mathrm{r}$ sebesar 0,104.[12]

Analisis kemampuan pemecahan masalah, telah banyak diteliti dan dikembangkan oleh para ahli diantaranya yang dilakukan oleh Arifin (2016), Sanhadi (2016), Liyana (2018) dan Sumarni (2018). Hasil analisis dilakukan terhadap kemampuan pemecahan masalah pada beberapa materi diantaranya program linear. Analisis menunjukkan bahwa kemampuan pemecahan masalah siswa dalam menyelesaikan soal program linear terbagi dalam berbagai tingkat. Selain itu kemampuan pemecahan masalah peserta didik jika ditinjau berdasarkan langkah Polya dapat dilihat persentasenya, yaitu jumlah siswa yang sudah melakukan langkah Polya dibandingkan dengan jumlah seluruh siswa.[13] Adapun tahapan yang dilihat dalam kemampuan pemecahan masalah ada empat yakni: memahami masalah, merencanakan penyelesaian, melaksanakan rencana penyelesaian dan memeriksa kembali jawaban.

Berdasarkan hal di atas kemampuan pemecahan masalah dapat terlihat ketika siswa sedang mempelajari materi program linear. Terdapat temuan yang menunjukkan kesulitan maupun kesalahan siswa dalam menyelesaikan masalah program linear. Program linear dipelajari pada tingkatan sekolah menengah atas yang mudah dihubungkan dengan masalah kehidupan sehari-hari. Salah satu faktor penyebab di duga karena ketidakyakinan siswa terhadap kemampuannya menyelesaikan masalah, namun perlu penelitian lebih lanjut untuk membuktikannya.[14] Oleh karena itu peneliti tertarik untuk mendeskripsikan kemampuan pemecahan masalah dan self efikasi siswa serta melihat bagaimana hubungan diantara keduanya.

\section{Metode Penelitian}

Penelitian ini di laksanakan di SMAN 1 Banuhampu yang terletak di Kabupaten Agam, Sumatera Barat dengan melibatkan 34 orang siswa SMA kelas XI MIPA. Adapun metode yang digunakan dalam penelitian ini adalah deskriptif-kualitatif. Metode ini digunakan untuk mendeskripsikan data kemampuan pemecahan masalah matematika siswa dengan pemberian tes dan tingkat efikasi diri yang diperoleh melalui pemberian angket efikasi diri serta melihat hubungan diantara keduanya. Tes kemampuan pemecahan masalah dan angket efikasi diri sudah divalidasi terlebih dahulu. Analisis data yang digunakan dalam penelitian ini adalah statistik deskriptif.

Penelitian ini diawali dengan pengumpulan data tingkat self-efficacy melalui angket. yang dikembangkan berdasarkan dimensi self-efficacy yaitu level, strength, dan generality [8]. Dimensi Magnitude memiliki efek pada pemilihan perilaku yang akan dicoba atau dikehendaki berdasarkan pengharapan self efikasi pada tingkat kesulitan soal yang diberikan. Individu akan 
mencoba perilaku yang dirasakan mampu untuk dilaksanakan. Sebaliknya ia akan menghindari situasi dan perilaku yang dirasa melampaui batas kemampuannya. Dimensi Strenght berkaitan dengan kemantapan hati terhadap keyakinan individu bahwa ia akan berhasil dalam menghadapi suatu permasalahan.Keyakinan diri sendiri bahwa ia akan berhasil melakukan suatu tindakan dan perkiraan atau estimasi diri bahwa tingkah laku yang dilakukan diri itu akan mencapai hasil tertentu. Dimensi Generality berkaitan dengan seberapa luas bidang yang diyakini untuk berhasil dicapai oleh individu. Beberapa pengharapan terbatas pada bidang perilaku khusus, sedangkan beberapa pengharapan mungkin menyebar pada berbagai bidang perilaku. Pemberian angket pada seluruh siswa bertujuan agar memperoleh informasi terkait tingkat self-efficacy. Indikator yang digunakan untuk mengembangkan butir-butir angket dapat dilihat pada Tabel 1.

Tabel 1. Pengukuran Self Afficacy dalam Soal Pemecahan Masalah

\begin{tabular}{ll}
\hline \multicolumn{1}{c}{ Dimensi } & \multicolumn{1}{c}{ Indikator } \\
\hline $\begin{array}{l}\text { Magnitude } \\
\text { (level) }\end{array}$ & $\begin{array}{l}\text { Keyakinan akan kemampuan menyelesaikan soal } \\
\text { dengan berbagai tingkat kesulitan } \\
\text { Keyakinan dapat memahami dan memilih strategi } \\
\text { dalam menyelesaikan soal }\end{array}$ \\
Strength & $\begin{array}{l}\text { Keyakinan akan usaha yang dilakukan dalam } \\
\text { menghadapi soal dan tantangan }\end{array}$ \\
Kenerality & $\begin{array}{l}\text { Keyakinan memperoleh hasil yang baik } \\
\text { Keyakinan berhasil mencapai tujuan dalam } \\
\text { pembelajaran matematika } \\
\text { Keyakinan dalam mengerjakan soal yang belum } \\
\text { pernah ditemuinya }\end{array}$ \\
\hline
\end{tabular}

Selanjutnya, angket self-efficacy terdiri dari 20 butir pernyataan dan masing-masing dengan lima skala. Skor tertinggi yang mungkin diperoleh responden yaitu 100 dan skor terendah yaitu 0. Data yang diperoleh dari angket kemudian dianalisis untuk membuat kategori siswa berdasarkan tingkat self-efficacy pada Tabel 2 .

Tabel 2. Kriteria Tingkat Self-Efficacy

\begin{tabular}{cc}
\hline Interval & Kriteria \\
\hline $\mathbf{9 1 - 1 0 0}$ & Sangat tinggi \\
$\mathbf{7 8 - 9 0}$ & Tinggi \\
$\mathbf{6 5 - 7 7}$ & Cukup tinggi \\
$\mathbf{5 2 - 6 4}$ & Sedang \\
$\mathbf{3 9 - 5 1}$ & Cukup rendah \\
$\mathbf{2 6 - 3 8}$ & Rendah \\
$\mathbf{1 4 - 2 5}$ & Sangat rendah \\
\hline & Sumber: $[15]$
\end{tabular}

Pengumpulan data selanjutnya dilakukan terhadap 34 siswa kelas XI MIPA 1 di SMAN 1 Banuhampu yang memiliki akreditasi A diberikan angket efikasi diri. Setelah itu, siswa diberikan tes kemampuan pemecahan masalah. Soal tes kemampuan pemecahan masalah seperti disajikan di bawah ini.

Seorang pembuat kue mempunyai $8 \mathrm{~kg}$ tepung dan $2 \mathrm{~kg}$ gula pasir. Ia ingin membuat dua macam kue yaitu kue lupis dan kue serabi. Untuk membuat kue lupis dibutuhkan 10 gram gula pasir dan 20 gram tepung sedangkan untuk membuat sebuah kue serabi dibutuhkan 5 gram gula pasir dan 50 gram tepung. Jika kue lupis dijual dengan harga Rp 1500/buah dan kue serabi dijual dengan harga Rp 1000/buah, tentukanlah pendapatan maksimum yang dapat diperoleh 
pembuat kue tersebut. Tentukan penyelesaiannya berdasarkan langkah-langkah pemecahan masalah.

Adapun kriteria penskoran kemampuan pemecahan masalah siswa dapat dilihat pada rubrik di bawah ini:

Tabel 3. Rubrik Kemampuan Pemecahan Masalah Siswa SMA

\begin{tabular}{|c|c|c|c|c|c|}
\hline \multirow{2}{*}{ No } & \multirow{2}{*}{ Kriteria } & \multicolumn{4}{|c|}{ Skala Penilaian } \\
\hline & & 1 & 2 & 3 & 4 \\
\hline 1 & $\begin{array}{l}\text { Memahami } \\
\text { masalah }\end{array}$ & $\begin{array}{l}\text { Siswa menulis hal- } \\
\text { hal yang tidak } \\
\text { sesuai dengan soal } \\
\text { dan tidak dapat } \\
\text { dipertanggungjawa } \\
\text { bkan }\end{array}$ & $\begin{array}{l}\text { Siswa menulis hal- } \\
\text { hal yang diketahui } \\
\text { tapi salah, tidak } \\
\text { lengkap, dan tidak } \\
\text { jelas, namun dapat } \\
\text { dipertanggungjawab } \\
\text { kan }\end{array}$ & $\begin{array}{l}\text { Siswa menulis } \\
\text { hal-hal yang } \\
\text { diketahui dalam } \\
\text { soal dengan } \\
\text { benar, namun } \\
\text { tidak dapat } \\
\text { dipertanggungja } \\
\text { wabkan }\end{array}$ & $\begin{array}{l}\text { Siswa menulis } \\
\text { hal-hal yang } \\
\text { diketahui dalam } \\
\text { soal dengan } \\
\text { lengkap, jelas dan } \\
\text { benar, serta dapat } \\
\text { dipertanggungjaw } \\
\text { abkan }\end{array}$ \\
\hline 2 & $\begin{array}{l}\text { Membuat } \\
\text { rencana } \\
\text { penyelesai } \\
\text { an }\end{array}$ & $\begin{array}{l}\text { Siswa menulis } \\
\text { rencana } \\
\text { penyelesaian yang } \\
\text { tidak sesuai dengan } \\
\text { soal dan tidak } \\
\text { dapat } \\
\text { dipertanggung- } \\
\text { jawabkan }\end{array}$ & $\begin{array}{l}\text { Siswa menulis } \\
\text { rencana } \\
\text { penyelesaian tapi } \\
\text { salah, tidak lengkap, } \\
\text { dan tidak jelas, } \\
\text { namun dapat } \\
\text { dipertanggung- } \\
\text { jawabkan }\end{array}$ & $\begin{array}{l}\text { Siswa menulis } \\
\text { rencana } \\
\text { penyelesaian } \\
\text { dengan benar, } \\
\text { namun dapat } \\
\text { tidak dapat } \\
\text { mempertang- } \\
\text { gungjawabkan }\end{array}$ & $\begin{array}{l}\text { Siswa menulis } \\
\text { rencana } \\
\text { penyelesaian } \\
\text { dengan lengkap, } \\
\text { jelas, dan benar, } \\
\text { serta dapat } \\
\text { dipertanggung- } \\
\text { jawabkan }\end{array}$ \\
\hline 3 & $\begin{array}{l}\text { Mengaplik } \\
\text { asikan } \\
\text { rencana } \\
\text { penyelesai } \\
\text { an }\end{array}$ & $\begin{array}{l}\text { Siswa menulis } \\
\text { penerapan rencana } \\
\text { penyelesaian yang } \\
\text { tidak sesuai dengan } \\
\text { soal dan tidak } \\
\text { dapat } \\
\text { dipertanggung- } \\
\text { jawabkan }\end{array}$ & $\begin{array}{l}\text { Siswa menulis } \\
\text { penerapan rencana } \\
\text { penyelesaian tapi } \\
\text { salah, tidak lengkap, } \\
\text { dan tidak jelas, } \\
\text { namun dapat } \\
\text { dipertanggung- } \\
\text { jawabkan }\end{array}$ & $\begin{array}{l}\text { Siswa menulis } \\
\text { penerapan } \\
\text { rencana } \\
\text { penyelesaian } \\
\text { dengan lengkap, } \\
\text { jelas dan benar, } \\
\text { namun tidak } \\
\text { dapat } \\
\text { mempertang- } \\
\text { gungjawabkan }\end{array}$ & $\begin{array}{l}\text { Siswa menulis } \\
\text { penerapan } \\
\text { rencana } \\
\text { penyelesaian } \\
\text { dengan lengkap, } \\
\text { jelas dan benar, } \\
\text { serta dapat } \\
\text { dipertanggung- } \\
\text { jawabkan }\end{array}$ \\
\hline 4 & $\begin{array}{l}\text { Memeriksa } \\
\text { kembali }\end{array}$ & $\begin{array}{l}\text { Siswa memeriksa } \\
\text { kembali } \\
\text { penyelesaian yang } \\
\text { tidak sesuai dengan } \\
\text { soal dan tidak } \\
\text { dapat } \\
\text { dipertanggung- } \\
\text { jawabkan }\end{array}$ & $\begin{array}{l}\text { Siswa memeriksa } \\
\text { kembali } \\
\text { penyelesaian tapi } \\
\text { salah, tidak lengkap, } \\
\text { dan tidak jelas, } \\
\text { namun dapat } \\
\text { dipertanggungjawab } \\
\text { kan }\end{array}$ & $\begin{array}{l}\text { Siswa memeriksa } \\
\text { kembali } \\
\text { penyelesaian } \\
\text { dengan benar, } \\
\text { namun tidak } \\
\text { dapat } \\
\text { mempertang- } \\
\text { gung jawabkan }\end{array}$ & $\begin{array}{l}\text { Siswa memeriksa } \\
\text { kembali } \\
\text { penyelesaian } \\
\text { dengan lengkap, } \\
\text { jelas, dan benar, } \\
\text { serta dapat } \\
\text { dipertanggung- } \\
\text { jawabkan }\end{array}$ \\
\hline
\end{tabular}

Sumber:[2]

Setelah diperoleh nilai kemampuan pemecahan masalah siswa dan skor angket maka dicari hubungan dengan menggunakan rumus korelasi product moment. Misalkan variabel X dengan nilai kemampuan aljabar siswa dan $\mathrm{Y}$ dengan skor angket siswa, dimana masing-masing memiliki skala dari 0 hingga 100.

$$
r=\frac{N \sum X Y-\left(\sum X\right)\left(\sum Y\right)}{\sqrt{N \sum X^{2}-\left(\sum X\right)^{2}} x \sqrt{N \sum Y^{2}-\left(\sum Y\right)^{2}}}
$$

Keterangan:

$\sum X Y=$ jumlah perkalian nilai-nilai kemampuan aljabar dan angket 
$\sum X=$ jumlah nilai-nilai kemampuan aljabar

$\sum Y=$ jumlah nilai-nilai kemampuan angket

$\sum X^{2}=$ jumlah kuadrat nilai-nilai kemampuan aljabar

$\sum Y^{2}=$ jumlah kuadrat nilai-nilai skor angket

$N=$ banyak pasangan nilai-nilai

Nilai r yang diperoleh kemudian di interpretasikan menurut table di bawah ini :

Tabel 4. Interpretasi terhadap Angka Indeks Korelasi "r" Product Moment

\begin{tabular}{cl}
\hline $\mathbf{0 , 0 0 - 0 , 2 0}$ & $\begin{array}{l}\text { Antara variable } \mathrm{x} \text { dan variable } \mathrm{y} \text { memang terdapat korelasi, akan tetapi } \\
\text { korelasi itu sangat lemah atau sangat rendah, sehingga korelasi itu } \\
\text { diabaikan (dianggap tidak ada korelasi antara variable } \mathrm{X} \text { dan variable } \mathrm{Y} \text { ) }\end{array}$ \\
\hline $\mathbf{0 , 2 - 0 , 4}$ & Antara variable $\mathrm{x}$ dan variable y terdapat korelasi yang lemah atau rendah \\
$\mathbf{0 , 4 - 0 , 7}$ & Antara variable $\mathrm{x}$ dan y terdapat korelasi yang sedang atau cukupan \\
$\mathbf{0 , 7 - 0 , 9}$ & Antara variable $\mathrm{X}$ dan variable $\mathrm{Y}$ terdapat korelasi yang kuat atau tinggi \\
$\mathbf{0 , 9 - 1}$ & Antara variable $\mathrm{x}$ dan variable y terdapat korelasi yang sangat kuat atau sangat \\
& tinggi \\
\hline
\end{tabular}

\section{Hasil dan Pembahasan}

\subsection{Deskripsi Kemampuan Pemecahan Masalah Siswa}

Berdasarkan tes yang sudah diberikan, hasil yang diperoleh dideskripsikan berdasarkan empat langkah pemecahan masalah menurut Polya. Adapun hasilnya dapat dilihat sebagai berikut:

Tabel 5. Analisis Pemecahan Masalah Matematis

\begin{tabular}{lccccc}
\hline & \multicolumn{5}{c}{ Skala Penilaian } \\
\cline { 2 - 6 } & 0 & 1 & 2 & 3 & 4 \\
\hline Memahami masalah & 0 & 0 & 0 & $53 \%$ & $47 \%$ \\
Membuat rencana penyelesaian & $3 \%$ & $12 \%$ & $53 \%$ & $29 \%$ & $3 \%$ \\
$\begin{array}{l}\text { Menerapkan strategi sesuai } \\
\text { rencana }\end{array}$ & 0 & 0 & $9 \%$ & $74 \%$ & $17 \%$ \\
Memeriksa jawaban kembali & $41 \%$ & $32 \%$ & $6 \%$ & $21 \%$ & 0 \\
\hline
\end{tabular}

Berdasarkan table 5 terlihat bahwa kemampuan pemecahan masalah siswa masih rendah pada tahap memeriksa kembali. Sementara itu, masih didapati juga siswa yang mengosongkan jawabannya.

\subsection{Deskripsi Tingkat Efikasi Siswa}

Hasil penskoran tingkat efikasi siswa diperoleh setelah siswa diberi angket self efikasi. Agar lebih jelasnya, dapat dilihat pada table di bawah ini:

Tabel 6. Distribusi Efikasi Diri Siswa

\begin{tabular}{cccc}
\hline Interval & Kriteria & Frekuensi & Persentase \\
\hline $\mathbf{9 1 - 1 0 0}$ & Sangat tinggi & 0 & 0 \\
$\mathbf{7 8 - 9 0}$ & Tinggi & 0 & 0 \\
$\mathbf{6 5 - 7 7}$ & Cukup tinggi & 11 & 32 \\
$\mathbf{5 2 - 6 4}$ & Sedang & 20 & 59 \\
$\mathbf{3 9 - 5 1}$ & Cukup rendah & 1 & 3 \\
$\mathbf{2 6 - 3 8}$ & Rendah & 2 & 6 \\
$\mathbf{1 4 - 2 5}$ & Sangat rendah & 0 & 0 \\
\hline Jumlah & & $\mathbf{3 4}$ & $\mathbf{1 0 0}$ \\
\hline
\end{tabular}


Dari 34 orang siswa yang menjawab, tidak ada self efikasi siswa yang berada pada level sangat rendah. Siswa yang memiliki self efikasi cukup tinggi ada sebelas orang. Pada umumnya, siswa berada pada level sedang dengan persentase 59. Sisanya berada pada level cukup rendah dan rendah sebanyak tiga orang. Adapun hasil angket efikasi diri dilihat berdasarkan dimensi Magnitude (level), Strength dan Generality dapat dilihat pada table di bawah ini.

Tabel 7. Distribusi Efikasi Diri Siswa Berdasarkan Dimensi

\begin{tabular}{cccc}
\hline No & Dimensi & No Pernyataan & Rataan Hitung \\
\hline $\mathbf{1}$ & Magnitude & $1 \mathrm{sd} 9$ & 3,15 \\
$\mathbf{2}$ & Generality & $10 \mathrm{sd} 14$ & 3,52 \\
$\mathbf{3}$ & Strength & $15 \mathrm{sd} 20$ & 3,12 \\
\hline
\end{tabular}

Dari tabel 7 diperoleh bahwa rataan hitung tingkat self efikasi siswa paling tinggi berada pada dimensi Generality sebesar 3,52. Kemudian dilanjutkan dimensi Magnitude dan Strength masing-masing sebesar 3,15 dan 3,12.

\subsection{Analisis Hubungan Antara Kemampuan Pemecahan Masalah dengan Efikasi Diri Siswa}

Berdasarkan deskripsi kemampuan pemecahan masalah dan self efikasi siswa di atas, dapat kita lihat hubungan keduanya dengan menggunakan analisis seperti di bawah ini:

$$
\begin{aligned}
& r=\frac{N \sum X Y-\left(\sum X\right)\left(\sum Y\right)}{\sqrt{N \sum X^{2}-\left(\sum X\right)^{2} x \sqrt{N \sum Y^{2}-\left(\sum Y\right)^{2}}}} \\
& r=\frac{(34 x 129.546)-(2.099 x 2.098)}{\sqrt{(34 x 133021)-4405801} x \sqrt{(34 x 131584)-4401604}} \\
& r=\frac{4404564-4403702}{341,93 \times 268,8} \\
& r=\frac{862}{91908,6} \\
& r=0,0094
\end{aligned}
$$

Dari perhitungan di atas diperoleh nilai $r=0,0094$ yang artinya antara kemampuan pemecahan masalah siswa dan efikasi diri siswa memang terdapat korelasi, akan tetapi korelasi itu sangat lemah atau sangat rendah, sehingga korelasi itu diabaikan (dianggap tidak ada hubungan kemampuan kemampuan pemecahan masalah dengan efikasi diri siswa. Hal ini juga sejalan dengan penelitian yang dilakukan tentang hubungan kemampuan pemecahan masalah matematika dan self-efficacy siswa termasuk kategori sangat rendah karena nilai r sebesar 0,104 [12].

Dapat disimpulkan bahwa terdapat faktor lain yang menyebabkan rendahnya kemampuan pemecahan masalah siswa seperti dalam penggunaan model pembelajaran.[6] Penggunaan model pembelajaran ekspositori yang selama ini digunakan oleh kebanyakan guru lebih menitikberatkan pada aktivitas guru dalam proses pembelajaran. Oleh karena itu, siswa kurang diberikan kesempatan untuk mengembangkan keterampilan dan pengetahuan yang diperoleh hanya sebatas apa yang dipelajarinya sehingga keterampilan berpikir tidak berkembang secara optimal, termasuk kemampuan pemecahan masalah. Selain model pembelajaran, faktor lain yang dapat berkontribusi terhadap perkembangan kemampuan pemecahan masalah dan kepercayaan diri siswa adalah kemampuan awal matematika siswa. Pengetahuan awal akan berdampak pada proses pembelajaran matematika yang optimal sehingga menjadikan pembelajaran lebih bermakna. 


\section{Kesimpulan}

Berdasarkan Penelitian yang telah dilakukan maka dapat dikatakan bahwa efikasi diri siswa SMA 1 Banuhampu tidak menjadi salah satu faktor penghambat dalam kemampuan pemecahan masalah siswa pada materi program linear. Selain itu, dalam pengerjaan soal masih terdapat siswa yang mengosongkan jawaban dan sedikit sekali siswa yang memeriksa kembali jawaban yang telah dibuatnya. Penelitian lanjutan perlu dilakukan untuk siswa pada sekolah lain dengan materi yang berbeda. Selain itu, factor penyebab kesulitan siswa dalam mengerjakan soal pemecahan masalah perlu ditemukan seperti tidak menguasai konsep prasyarat atau yang lain.

\section{Daftar Pustaka}

[1] H. Ulya, "Sejarah artikel," J. Konseling Gusjigang PGSD Univ. Muria Kudus, vol. 2, no. 1, pp. 90-96, 2016.

[2] I. K. Sari, "Profil pemecahan masalah matematis siswa usia 14-15 tahun di Banda Aceh," Numeracy, vol. III, no. July, pp. 1-23, 2016.

[3] P. Firmanti, T. Rahmat, F. Yuberta, and H. Fitri, "Build Character of Hard Work through Problem Solving Strategies (Intelligent Guessing and Testing in Mathematics)," J. Phys. Conf. Ser., vol. 1471, no. 1, 2020, doi: 10.1088/1742-6596/1471/1/012031.

[4] R. Oktaviyanthi and R. N. Agus, "Eksplorasi Kemampuan Pemecahan Masalah Berdasarkan Kategori Proses Literasi Matematis," J. Pendidik. Mat., vol. 13, no. 2, pp. 163-184, 2019, doi: 10.22342/jpm.13.2.7066.163-184.

[5] M. Ilmiyana, "Analisis Kemampuan Pemecahan Masalah dari Tipe Kepribadian Dimensi MBTI," Gammath, pp. 130-143, 2018.

[6] E. Surya, F. A. Putri, and Mukhtar, "Improving mathematical problem-solving ability and self-confidence of high school students through contextual learning model," J. Math. Educ., vol. 8, no. 1, pp. 85-94, 2017, doi: 10.22342/jme.8.1.3324.85-94.

[7] L. T. Medyasari, Z. Zaenuri, and N. R. Dewi, "Kemampuan Pemecahan Masalah Matematis Siswa SMA Negeri 5 Semarang," Prism. Pros. Semin. Nas. Mat., vol. 3, pp. 464-470, 2020.

[8] A. Bandura, W. H. Freeman, and R. Lightsey, "Self-Efficacy: The Exercise of Control," Journal of Cognitive Psychotherapy, vol. 13, no. 2. pp. 158-166, 1999, doi: 10.1891/08898391.13.2.158.

[9] A. Ardiansyah, "Penguasaan Konsep Matematika Ditinjau dari Efikasi Diri dan Kemandirian Belajar," Alfarisi, vol. 1, no. 1, pp. 1-8, 2018.

[10] F. Pajares and J. Kranzler, "Self-efficacy beliefs and general mental ability in mathematical problem-solving," Contemp. Educ. Psychol., vol. 20, no. 4, pp. 426-443, 1995, doi: 10.1006/ceps.1995.1029.

[11] Y. Sukma and N. Priatna, "Pengaruh Self-Efficacy terhadap Kemampuan Berpikir Kritis Siswa Pada Mata Pelajaran Matematika," J. Ilm. Soulmath J. Edukasi Pendidik. Mat., vol. 9, no. 1, pp. 75-88, 2021, doi: 10.25139/smj.v9i1.3461.

[12] R. W. Utami and D. U. Wutsqa, "Analisis kemampuan pemecahan masalah matematika dan self-efficacy siswa SMP negeri di Kabupaten Ciamis," J. Ris. Pendidik. Mat., vol. 4, no. 2, p. 166, 2017, doi: 10.21831/jrpm.v4i2.14897.

[13] A.- Rosydiana, "Analisis Kemampuan Siswa Dalam Menyelesaikan Soal Cerita Berdasarkan Langkah Pemecahan Masalah Polya," Math. Educ. J., vol. 1, no. 1, p. 54, 2017, doi: 10.22219/mej.v1i1.4550. 
[14] A. Imaroh, U. Umah, and T. M. Asriningsih, "Analisis kemampuan pemecahan masalah matematika ditinjau dari self-efficacy siswa pada materi sistem persamaan linear tiga variabel," Inov. J. Pembelajaran Mat., vol. 4, no. 4, pp. 843-856, 2021, doi: 10.22460/jpmi.v4i4.843-856.

[15] Yoni Sunaryo, "Pengukuran Self-Efficacy Siswa dalam Pembelajaran Matematika di MTsN 2 Ciamis," J. Teor. dan Ris. Mat., vol. 1, no. 2, pp. 39-44, 2017.

[16] P. D. A. Sudijono, Pengantar statistik pendidikan, 1st ed. Jakarta: PT Raja Grafindo Persada, 2005. 